\title{
A deletion of the human $\beta$-globin locus activation region causes a major alteration in chromatin structure and replication across the entire $\beta$-globin locus
}

\author{
William C. Forrester, ${ }^{1,2}$ Elliot Epner, ${ }^{1}$ M. Catherine Driscoll, ${ }^{3}$ Tariq Enver, ${ }^{4}$ Martha Brice, ${ }^{4}$ Thalia \\ Papayannopoulou, ${ }^{4,6}$ and Mark Groudine ${ }^{1,5,6}$ \\ ${ }^{1}$ Fred Hutchinson Cancer Research Center, Seattle, Washington 98104 USA; Departments of ${ }^{2}$ Pathology, ${ }^{4}$ Medicine, \\ ${ }^{5}$ Radiation Oncology, University of Washington, Seattle, Washington 98195 . ${ }^{3}$ Department of Pediatrics, School of Medicine, \\ Cornell University, New York, New York 10021 USA
}

\begin{abstract}
Naturally occurring deletions that remove sequences located $\sim 60 \mathrm{~kb}$ upstream of the human adult $\beta$-globin gene result in the failure to transcriptionally activate the cis-linked globin genes in erythroid cells. In addition, transfection, transgenic, and somatic cell hybrid studies have revealed that sequences within this region are essential for the developmentally regulated high-level expression of cis-linked globin genes. This regulatory region located at the $5^{\prime}$ end of the $\beta$-globin locus has been termed the locus activation region (LAR). Using somatic cell hybrids, we have studied the chromatin structure and timing of DNA replication of the normal human $\beta$-globin locus and a locus containing a de novo $25-\mathrm{kb}$ deletion that removes elements of the LAR. As a result of this deletion, the entire $\beta$-globin locus and sequences $\sim 100 \mathrm{~kb} 5^{\prime}$ and $3^{\prime}$ of the adult $\beta$-globin gene are DNase I-resistant and do not form characteristic distant hypersensitive sites. These sequences also replicate late in $\mathrm{S}$ phase in an erythroid cell background. In contrast, the sequences of the normal locus are DNase I sensitive and early replicating. These results suggest that the LAR is required for both the erythroid-specific chromatin structure and timing of DNA replication over a large physical distance.
\end{abstract}

[Key Words: $\beta$-Globin gene; locus activation region]

Received May 10, 1990; revised version accepted August 6, 1990.

The human $\beta$-globin locus consists of six $\beta$-like globin genes that occupy $\sim 50 \mathrm{~kb}$ on the short arm of chromosome 11 , in the $5^{\prime}$ to $3^{\prime}$ order: $\epsilon^{-}{ }^{\mathrm{G}}{ }_{-}{ }^{\mathrm{A}} \gamma-\psi \beta-\delta-\beta$ (for review, see Karlsson and Nienhuis 1985). Expression of these genes is restricted to cells of the erythroid lineage and is developmentally regulated such that only a subset is transcriptionally active at any particular developmental stage. These two aspects of globin gene control, erythroid and developmental specificity, appear to be regulated by separate cis-acting mechanisms. This is inferred from the phenotypes associated with naturally occurring mutations in and around the $\beta$-globin gene locus (for review, see Chapters 3 and 4 in Stamatoyannopoulos and Nienhuis 1987). For example, in the $(\gamma \delta \beta)^{0}$-thalassemias, deletions of the $5^{\prime}$ end of this locus prevent the transcriptional activation of any of the cis-linked $\beta$-globin genes at any developmental stage (Wood et al. 1979; Taramelli et al. 1986). In contrast, in both the deletional and mutational forms of the hereditary persistence of

'Senior authors. fetal hemoglobin disorders (HPFH), the cis-linked fetal globin genes continue to be expressed in adult erythroid cells (Tuan et al. 1983; Collins et al. 1987).

Chromatin structure analyses have revealed that the entire $\beta$-globin locus, including noncoding sequences and transcriptionally active and inactive genes, is preferentially sensitive to DNase I in erythroid cells /Groudine et al. 1983a,b; Forrester et al. 1986; Elder et al. 1990). These studies have also shown that erythroid-specific DNase I hypersensitive sites are located adjacent to transcriptionally active $\beta$-like globin genes /Groudine et

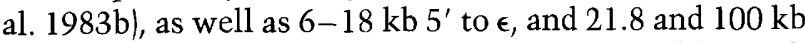
$3^{\prime}$ to $\beta$ (Tuan et al. 1985; Forrester et al. 1987; Elder et al. $1990)$. Unlike the gene-proximal hypersensitive sites, the sites $5^{\prime}$ to $\epsilon$ and $3^{\prime}$ to $\beta$ are present at all stages of development (embryonic, fetal, and adult) and are therefore referred to as developmentally stable. The general DNase I sensitivity of the locus and the developmentally stable hypersensitive sites are both established in immature erythroid cells prior to overt globin gene transcription (Forrester et al. 1987). In addition, either all or 
a subset of the developmentally stable hypersensitive sites upstream of the $\epsilon$-globin gene are deleted in cis to the inactive $\beta$-globin genes in every $(\gamma \delta \beta)^{0}$-thalassemia described thus far (see below). Thus, the $5^{\prime} \epsilon$ region containing the developmentally stable hypersensitive sites has been referred to as the locus activation region (LAR; Forrester et al. 1987; Wall et al. 1988). A subsequent and alternate designation, that of the dominant control region (DCR), has also been used to describe this region (Blom van Assendelft et al. 1989; Talbot et al. 1989).

Sequences within the LAR have been shown to confer high-level, erythroid-specific expression to $\beta$-globin genes linked in cis in transfected cell lines (Blom van Assendelft et al. 1989; Forrester et al. 1989; Talbot et al. 1989; Collis et al. 1990), transgenic mice (Grosveld et al 1987; Ryan et al. 1989b), and retrovirally infected cells (Novak et al. 1990). Although the strongest effects are seen when all of the hypersensitive sites are linked together, individual sites can exert transcriptional effects and certain combinations of individual sites can also augment expression (Forrester et al. 1989; Ryan et al. 1989b; Tuan et al. 1989; Collis et al. 1990). Recent studies in transgenic mice also suggest that the LAR may be involved in stage-specific gene expression (Behringer et al. 1990; Enver et al. 1990) in a manner analogous to the enhancer competition model described for chicken $\beta$-like globin gene switching (Choi and Engel 1988; Gallarda et al. 1989).

The mechanism by which the LAR influences endogenous $\beta$-globin gene expression is not known. Although an erythroid-specific enhancer has been found within the LAR (Tuan et al. 1989), when tested in transgenic mice or cell lines, this enhancer alone does not confer the high levels of transcription observed when cassettes containing additional sequences from the native LAR are used (Forrester et al. 1989; Ryan et al. 1989b; Collis et al. 1990). LAR sequences other than this enhancer are capable of augmenting transcription of cis-linked genes following stable transformation into MEL cells (Forrester et al. 1989; Collis et al. 1990), suggesting that normal levels of $\beta$-globin RNA in vivo may be achieved by cooperative interactions among multiple elements within the LAR and not exclusively through the action of this enhancer. In addition, it remains to be determined whether any LAR sequences function as enhancers when located in their natural chromosome position $>50 \mathrm{~kb}$ from the $\beta$-globin gene.

Prior to the identification of the LAR, it was observed that transfected or transgenic $\beta$-like globin genes could be regulated along with endogenous globin genes. In transgenic mice, human fetal $\gamma$ - and adult $\beta$-globin transgenes are expressed in $20-30 \%$ of the mice containing transgenes, and in these mice, the levels of expression of the human globin genes are considerably less than the mouse globin genes (Townes et al. 1985; Magram et al. 1985; Chada et al. 1986; Kollias et al. 1986; Curtin et al. 1989; Ryan et al. 1989b). Expression of these transgenes is tissue-specific and developmentally correct, indicating that individual globin genes contain sufficient sequence information to respond to both tissue- and stage-specific factors and do not require the LAR for these functions. Variable, but regulated, expression of transfected globin genes has also been observed. For example, although the level of expression of individual human $\beta$-globin genes transfected into MEL cells varies, the response of the exogenous human genes to chemical inducers parallels that of the endogenous murine adult globin genes (Wright et al. 1983, 1984; Charnay et al. 1984). Taken together, these observations suggest that although exogenous globin genes can be active and regulated in erythroid cells, the expression of individual genes is made more efficient by the LAR.

In contrast to the expression of transfected globin genes and transgenes, the same (wild-type) human $\beta$ globin genes are not active at their normal chromosomal locations in the deletional $(\gamma \delta \beta)^{0}$-thalassemias. Three members of the $(\gamma \delta \beta)^{0}$ class of deletional thalassemias have been described: the Dutch (Van der Ploeg et al. 1980), English (Curtin et al. 1985) and, most recently, the Hispanic (Driscoll et al. 1989), all of which are characterized by overlapping deletions of the $5^{\prime}$ end of the $\beta$-globin locus. Analysis of the Dutch $(\gamma \delta \beta)^{0}$-thalassemia revealed that the unexpressed $\beta$-globin gene is in a DNase I-resistant configuration in fetal liver cells but behaves similarly to a wild-type globin gene in transfection assays (Kioussis et al. 1983). Thus, because these deletions prevent the transcriptional activation of the structurally intact and potentially functional $\beta$-like globin genes downstream of the breakpoints, sequences removed by these deletions most likely contain regulatory elements that are required for expression of any of the globin genes in cis. The LAR normally resides in the regions deleted in the $(\gamma \delta \beta)^{0}$-thalassemias, making it likely that the molecular defect in these diseases is the absence of the LAR.

In addition to structural and functional analyses, the timing of DNA replication of sequences within the $\beta$ globin locus has also been studied. Previous work established that active genes replicate in the early part of $S$ phase (for review, see Goldman et al. 1984; Holmquist 1987). In both immature and mature erythroid cells, the entire $\beta$-globin locus DNase I-sensitive domain, including active and inactive genes and nontranscribed flanking sequences, replicates early in $S$ phase (Epner et al. 1981, 1988; Dhar et al. 1988). However, sequences 5' to the $\beta$-globin locus that reside within DNase I-resistant chromatin also replicate early in S phase in erythroid cells (Epner et al. 1988). Therefore, patterns of DNA replication do not strictly correlate with domains of DNase I sensitivity, indicating that these features may be controlled by separate elements.

We have used somatic cell hybrids as a model system to address the manner by which distant sequences may influence the chromatin structure, transcriptional activation, and/or timing of replication of downstream globin genes. In these hybrids, human nonerythroid cells are fused with mouse erythroleukemia (MEL) cells, leading to the trans-activation of the human adult erythroid program (Willing et al. 1979; Pyati et al. 1980; Papayannopoulou et al. 1986; Takegawa et al. 1986). 
MEL cells are adult erythroid cell precursors and stimulate the expression of the human adult $\alpha$-and $\beta$-like globin genes, as well as other erythroid-specific genes in the human nonerythroid fusion partner (Deisseroth and Hendrick 1978; Baron and Maniatis 1986; Raich et al. 1989). Previous work has shown that these hybrids faithfully reproduce normal and mutant globin gene expression and thereby constitute a model system to study globin gene regulation (Papayannopoulou et al. 1988).

In an effort to better understand the basis for tissuespecific activation of the $\beta$-globin locus, we have studied the consequences of the Hispanic $(\gamma \delta \beta)^{0}$-thalassemia deletion in somatic cell hybrids. In these hybrids, unlike hybrids containing a normal globin locus, the $\beta$-globin gene $60 \mathrm{~kb} \mathrm{3}$ ' to the deletion, is transcriptionally inactive, DNase I resistant, and late replicating. In addition, the entire locus, as well as the distant $\left(100 \mathrm{~kb} 3^{\prime}\right.$ to $\left.\beta\right)$ HPFH region, is also DNase I resistant. Developmentally stable hypersensitive sites not removed by the deletion are not formed, and all probes tested including the distant 5' $\epsilon$ and $3^{\prime}$ HPFH regions reside within late replicating DNA. Therefore, the requirement of the LAR for normal levels of $\beta$-globin gene expression may be due, in part, to the role that these sequences play in the establishment of an early replicating and/or a DNase I-sensitive chromatin structure over a large physical distance.

\section{Results}

\section{Hybrids containing the deleted chromosome}

The three deletional $(\gamma \delta \beta)^{0}$-thalassemias thus far analyzed are heterogeneous in terms of the size and location of the deletions. The $3^{\prime}$ breakpoints of the Dutch, English, and Hispanic deletions are 2.5-, 25-, and 60-kb 5' to the $\beta$-globin gene and remove $\sim 100,>90$, and, $35 \mathrm{~kb}$, respectively. The Hispanic deletion, is the smallest deletion, as well as the farthest away from the inactive $\beta$ globin gene. Therefore, this deletion is the most informative for identifying $\beta$-globin locus regulatory elements that may act over a large physical distance.

Restriction maps of the $5^{\prime} \epsilon$ region from the normal $\beta$ globin locus and the Hispanic deletion are shown in Figure 1. The positions of the developmentally stable hypersensitive sites in the normal locus and the $5^{\prime}$ and $3^{\prime}$ breakpoints of the deletion are also shown. The $3^{\prime}$ deletion breakpoint (right-hand end of bold line) is $\sim 10 \mathrm{~kb}$ upstream of the $\epsilon$-globin gene, and the $5^{\prime}$ breakpoint is within the $1.5-\mathrm{kb} E c o \mathrm{RI}$ fragment, located $\sim 45 \mathrm{~kb}$ upstream of the $\epsilon$-globin gene and is shown as an open box (not shown). The deletion creates a novel EcoRI junction fragment that is detected by a probe derived from a normal, undeleted chromosome (labeled probe in Fig. 1). In lymphoid cells from the thalassemia patient, this probe detects the 10.4-kb EcoRI fragment from the normal chromosome, as well as the $1.7-\mathrm{kb}$ EcoRI fragment from the deleted chromosome.

To study the effects of this deletion on expression of the otherwise intact $\beta$-globin locus in erythroid cells, we made hybrids between lymphoid cells from this patient and MEL cells. In these hybrids, in the absence of a selectable phenotype, human chromosomes are preferentially lost during propagation (Takegawa et al. 1986). Human chromosome 11, which contains the $\beta$-globin locus, does not contain a gene known to confer a dominant selectable phenotype. However, a monoclonal anti-

Map of the LAR in Normal and Hispanic $(\gamma \delta \beta)^{\circ}$-thal $\beta$-globin Loci

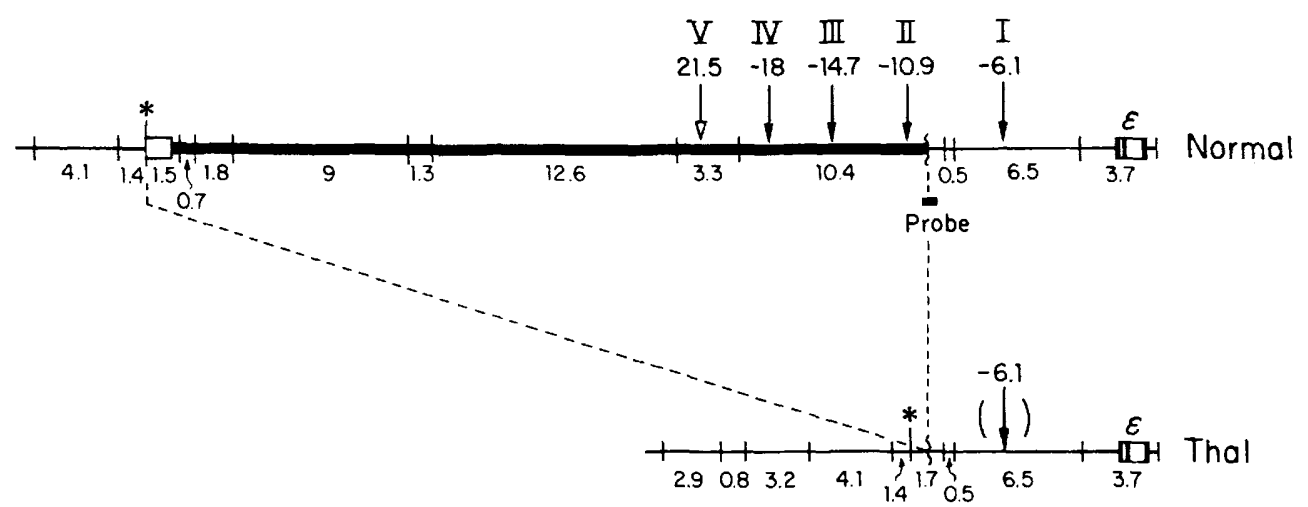

Figure 1. The 5' end of the $\beta$-globin locus showing details of the LAR and the Hispanic thalassemia deletion. The embryonic $\beta$-like globin gene, $\epsilon$, is the most $5^{\prime}$ of the $\beta$-like globin genes and is shown as a box at the far right end with exons and introns filled and open, respectively. Developmentally stable, erythroid-specific hypersensitive sites are shown as solid black arrows. Another hypersensitive site at $-21.5(\mathrm{~V})$, which is not erythroid specific, is shown with an open arrowhead. These hypersensitive sites are labeled according to their distance upstream from the $\epsilon$-globin gene transcription initiation site. Roman numeral nomenclature is taken from Tuan et al. (1985). Lines labeled Normal and Thal illustrate the structure of this region in the normal and deleted (Hispanic thalassemia) chromosome. The region deleted from the normal locus is shown as a bold black line. Short vertical lines show the locations of EcoRI sites, with sizes below (in kb; EcoRI map taken from Taramelli et al. 1986). Asterisk ( ${ }^{*}$ ) in normal map indicates probable candidates for $5^{\prime}$ the EcoRI site in novel EcoRI fragment created by deletion. The $3^{\prime}$ deletion breakpoint is shown as a wavy vertical line; the $5^{\prime}$ breakpoint falls within the open box. 
body specific for a constitutively expressed surface antigen encoded by a gene resident on chromosome 11 allows for the selection of hybrids containing this chromosome (see Materials and methods; Papayannopoulou et al. 1986; Takegawa 1986). Clonal cell lines derived from the lymphoid-MEL hybrids were isolated and characterized, as shown in Figure 2A. Clones containing either the normal or thalassemic chromosome (N-MEL or T-MEL, respectively) were identified on the basis of the size of EcoRI fragments. Of 25 independent hybrid clones, 15 contained exclusively the normal chromosome 11, 4 contained exclusively the thalassemic chromosome, and 6 contained both. Human $\beta$-globin gene expression in representative hybrids was determined by RNase protection, as shown in Figure 2B. $\beta$-Globin RNA was found only in the hybrids containing the normal chromosome and not in clones that contained exclusively the deleted chromosome (Fig. 2B). In hybrids containing the normal chromosome, levels of human $\beta$ -
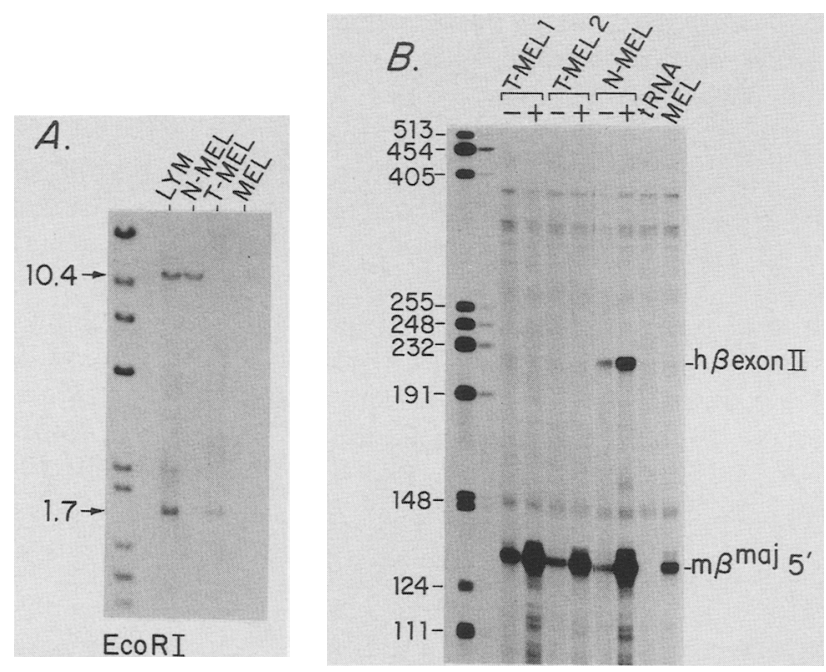

Figure 2. Southern blots and RNA analysis of somatic cell hybrids. (A) DNA from lymphoid cells from the thalassemic individual (Lym), from clonal hybrid cell lines between MEL cells and these lymphoid cells containing either the normal chromosome (N-MEL) or the deleted (T-MEL) chromosome, and from MEL cells was digested with EcoRI and probed with a $0.8-\mathrm{kb}$ $\mathrm{NCO}-\mathrm{Bg} I \mathrm{II}$ fragment labeled probe below the map of the normal chromosome in Fig. 1. Incomplete digestion results in the appearance of additional bands in the lymphoid cell lane. $(B)$ RNase protection of total RNA from uninduced $(-)$ and induced $(+)$ hybrids. RNA probes for the human $\beta$-globin and

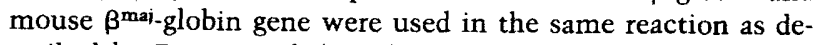
scribed by Enver et al. (1990). Lane tRNA contains no added cellular RNA; lane MEL contains RNA from parental MEL cells, prior to fusion. Densitometric tracings of a lighter exposure of $B$ showed that after correcting for the specific activity of the human and mouse RNA probes, the amount of human $\beta$ globin RNA is $20 \%$ that of the mouse. To normalize the level of mouse $\beta$-globin RNA to a per gene copy, the mouse RNA level is divided by four (the number of endogenous mouse $\beta$-globin genes contributing to this RNA pool) and multiplied by 0.8 ( $80 \%$ of the hybrid cells retain human chromosome 11 ). Following these normalizations, the human $\beta$-globin gene is expressed at $94-100 \%$ of the endogenous mouse levels. globin RNA are roughly equivalent to that of the endogenous mouse $\beta$-globin genes when normalized to copy number (Fig. 2B). Using a monoclonal antibody that rec-

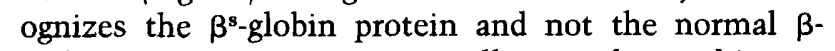
globin protein, no $\beta^{s}$-positive cells were detected in any of the 10 clonal hybrid lines containing the Hispanic chromosome (data not shown). Therefore, neither $\beta^{\text {s. }}$ globin RNA nor protein is detectable in any of the hybrids, either in clonal populations or in single cells, consistent with the $\beta^{0}$-thalassemia phenotype initially described for this patient.

\section{Chromatin structure}

The region lost as a result of the deletion includes sequences corresponding to all of the developmentally stable, erythroid-specific hypersensitive sites within the LAR, except for the -6.1 site (site I). Thus, the -6.1 region is not sufficient for transcriptional activation of the $\beta$-globin gene. Although it is not clear how different elements within the LAR affect globin gene expression, activity of the LAR has been correlated with the presence of the erythroid-specific hypersensitive sites. Therefore, we sought to determine whether, in the absence of other elements of the LAR, sequences within the -6.1 region are sufficient for the formation of the previously described erythroid-specific -6.1 hypersensitive site. For this experiment, nuclei from hybrid clone T-MEL-1, (hereafter referred to as T-MEL), containing only the deleted chromosome, were treated with increasing amounts of DNase I. DNA was subsequently purified from these samples and used to analyze the chromatin structure of the -6.1 region on the deleted chromosome. The results are shown in Figure 3A. Previous analyses using the same restriction enzyme and probe combination on DNA from human lymphoidMEL cell hybrids, as well as from normal adult and fetal human erythroid cells, identified the -6.1 hypersensitive site as a 2.5-kb sub-band (Forrester et al. 1986, 1987). However, in T-MEL cells, no hypersensitive site within this interval was found (Fig. 3A; T-MEL). When MEL hybrids containing the normal chromosome (N-MEL) from this patient were analyzed, the $2.5-\mathrm{kb}$ subband was present (Fig. 3A; N-MEL). To control for the DNase I digestion conditions, the same T-MEL samples were hybridized with a probe for the human catalase gene /Quan et al. 1986), which, like the $\beta$-globin locus, resides on chromosome 11 (van Heyningen et al. 1985). The results of this experiment show that hypersensitive sites on chromosome 11 are readily detected both in the T-MEL and N-MEL samples (Fig. 3B). The samples that display the $2.5-\mathrm{kb}$ subband most prominently in the N-MEL cells (Fig. 3A) are the same samples that contain the most prominent subbands for the $5^{\prime}$ catalase region. In T-MEL cells (Fig. 3B), catalase hypersensitive sites are strongest in lanes $8-11$; however, no subbands in these samples are seen in T-MEL (Fig. 3A).

The absence of the -6.1 hypersensitive site in T-MEL chromatin might be a reflection of a localized effect, due to the relative proximity of the deletion endpoint, $\sim 4.5$ 


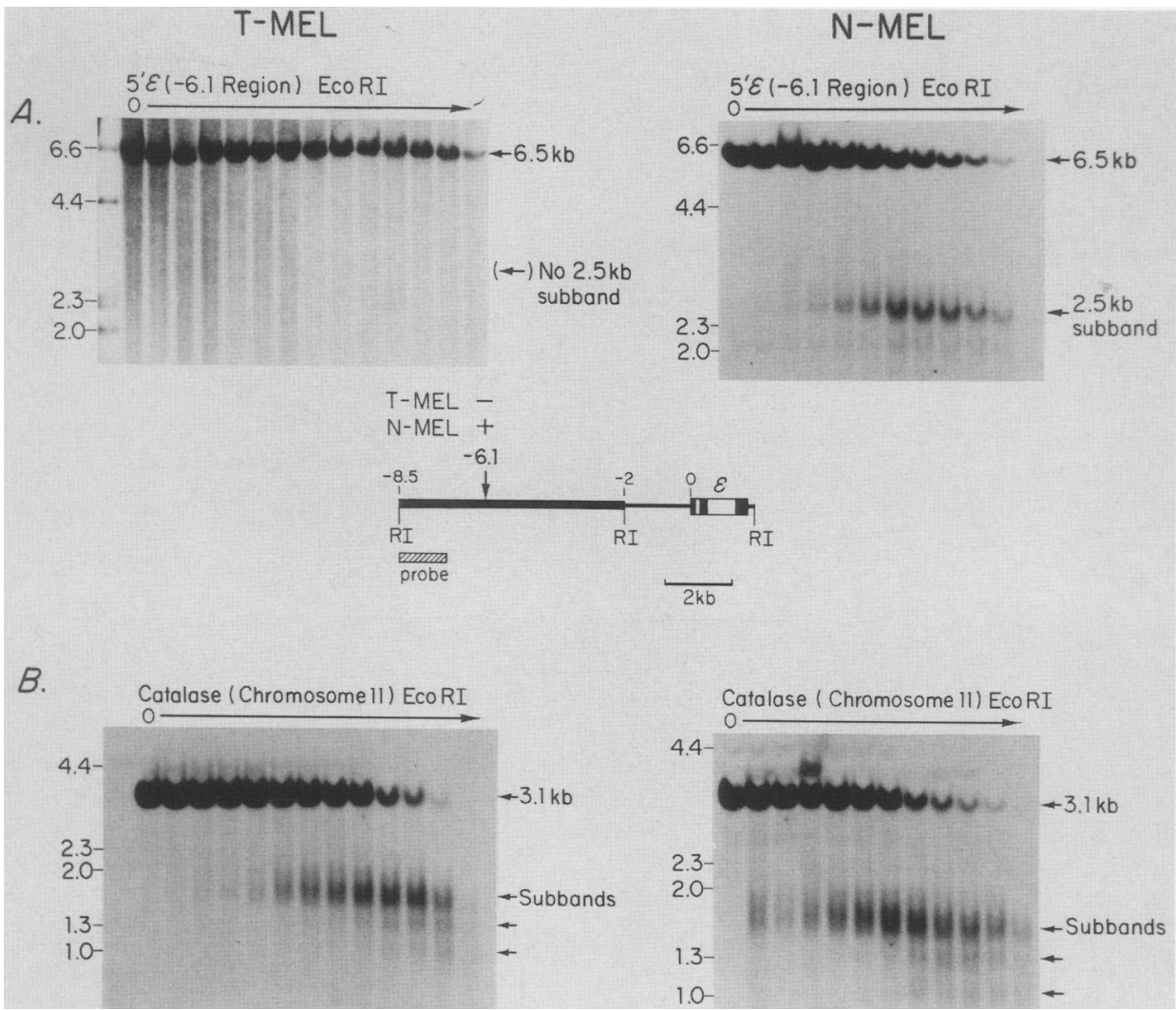

Figure 3. The $5^{\prime} \epsilon$ region is devoid of hypersensitive sites in T-MEL hybrids. Nuclei from T-MEL and N-MEL hybrids were treated with DNase I and extracted, and purified DNA was subsequently digested with EcoRI. $(A)$ Results of T-MEL and N-MEL experiments following hybridization to a $1.4-\mathrm{kb}$ EcoRI-Xba fragment shown as hatched bar in the map below. The $6.5 \mathrm{~kb}$ parent fragment is shown as a bold line in the map, and the expected position of the $2.5-\mathrm{kb}$ subband which corresponds to the -6.1 hypersensitive site, is indicated for T-MEL and N-MEL. The presence or absence of this subband is indicated by a plus $(+)$ or a minus $(-)$ above the -6.1 arrow in the map. $(B)$ The same filters in $A$ were rehybridized to a $3.1-\mathrm{kb} E c o$ RI fragment spanning the $5^{\prime}$ end of the human catalase gene. T-MEL samples are shown on the left; N-MEL samples are on the right.

$\mathrm{kb}$ upstream. Alternatively, the failure of this site to form may be due to the loss of sequences within the deletion that are necessary for the generation of this and other $\beta$-globin locus hypersensitive sites. Thus, to determine whether the deletion results in a localized inhibitory effect or a more global phenomenon, we used the same DNase I-digested samples to analyze two other developmentally stable hypersensitive sites located 75 and $\sim 155 \mathrm{~kb}, 3^{\prime}$ to the deletion breakpoint $\{21.8$ and $\sim 100$ $\mathrm{kb}, 3^{\prime}$ to the $\beta$-globin gene). The $3^{\prime} \beta$-globin +21.8 hypersensitive site is detected as a $4.3 \mathrm{~kb}$ subband when genomic DNA is digested with EcoRI and hybridized with the $3^{\prime} \beta$-globin 0.9-kb HindIII-EcoRI probe (Forrester et al. 1987). The results shown in Figure 4A are similar to the results obtained in the analysis of the $5^{\prime} \epsilon$ region: The 3' $\beta$ developmentally stable hypersensitive site is not detected in T-MEL chromatin but is present in N-MEL chromatin. Similarly, a third erythroid-specific developmentally stable hypersensitive site located within the HPFH region, $\sim 100 \mathrm{~kb} 3^{\prime}$ to the $\beta$-globin gene (Collins et al. 1987; Elder et al. 1990), is absent in T-MEL chromatin but present in N-MEL chromatin (Fig. 4B). This hypersensitive site is detected as a $1.5-\mathrm{kb}$ sub- band when N-MEL DNA is digested with SacI and hybridized with a 1.08-kb SacI-BamHI probe, as described previously (Elder et al. 1990). Thus, three erythroid-specific, developmentally stable hypersensitive sites $\left(5^{\prime} \epsilon\right.$ $-6.1,3^{\prime} \beta+21.8$, and HPFH), characteristic of the normal human $\beta$-globin locus, are not formed in the $\beta$ globin locus associated with the Hispanic deletion.

The hypersensitive sites described in Figures 3 and 4 are found in normal erythroid cells and hybrids in which the chromatin structure of the locus is DNase I sensitive. Because the sequences that normally contain these hypersensitive sites are so distant from one another, the absence of these sites in T-MEL might reflect a generalized DNase I-resistant chromatin structure of the $\beta$ globin locus. To address this question, we determined the overall DNase I sensitivity of the $\beta$-globin locus in T-MEL chromatin. A probe shown previously to reside within DNase I-sensitive chromatin in MEL cells, located $\sim 200$ bp $3^{\prime}$ to the mouse $\beta^{\text {mai-globin gene (Cohen }}$ and Sheffery 1985), was hybridized to EcoRI- or PstI-digested T-MEL DNA. This probe detects a 7-kb EcoRI and a 4.3-kb PstI fragment, both of which are devoid of hypersensitive sites in this experiment (data not shown). 

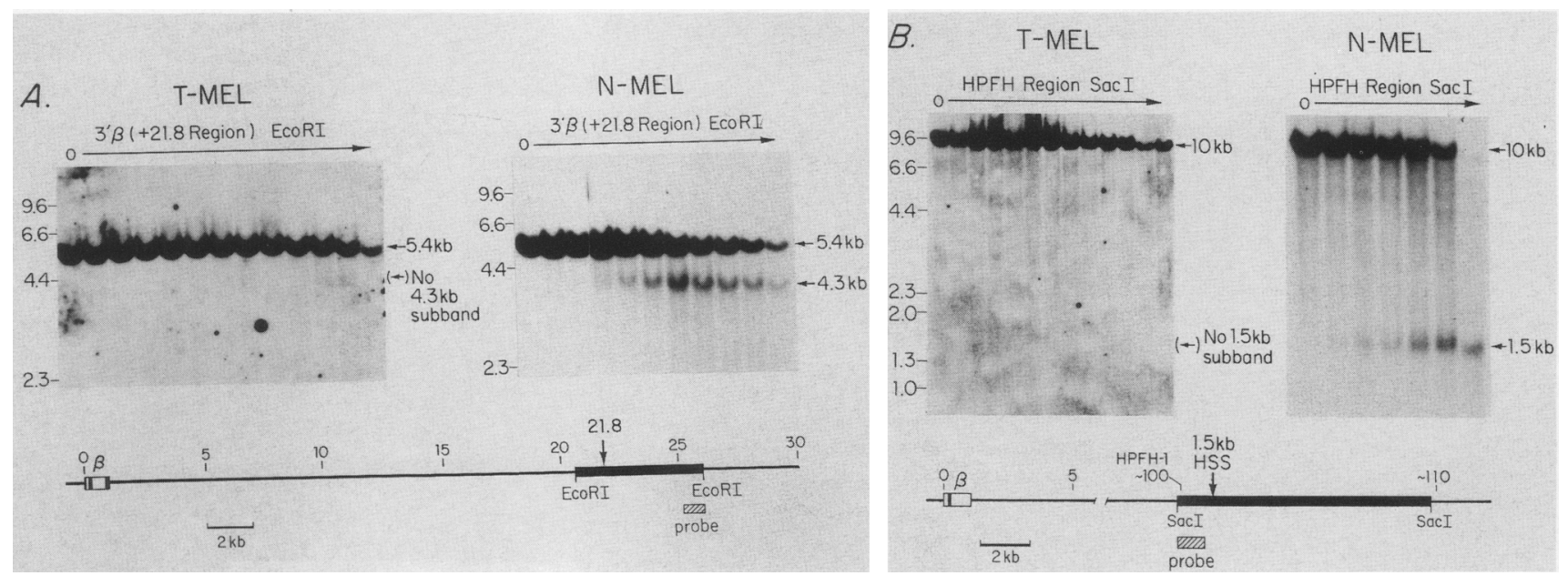

Figure 4. Developmentally stable hypersensitive sites $3^{\prime}$ to the $\beta$-globin gene and within the HPFH region are absent in T-MEL cells. DNA from DNase I-treated T-MEL nuclei was digested with either EcoRI $(A)$ or SacI $(B)$. $(A)$ Map of the 3 ' $\beta$-globin region $(b o t t o m)$ shows the position of the parent fragment (bold line), probe used (hatched bar), and location of the +21.8 hypersensitive site. The 0.9-kb HindIII-EcoRI probe hybridizes to a 5.4-kb EcoRI fragment and, in normal human erythroid cells (data not shown) and N-MEL hybrids, detects a 4.3-kb sub-band. The absence of the 4.3-kb sub-band in the T-MEL samples is shown as an arrow in parentheses at the position where a $4.3-\mathrm{kb}$ fragment should be found. $(B)$ Similar analysis of the HPFH region located $100 \mathrm{~kb} 3^{\prime}$ to the $\beta$-globin gene. The map (bottom) depicts the location of the probe (1.08-kb SacI-BamHI), HPFH-1 deletion breakpoint and erythroid-specific hypersensitive site within the HPFH region $\sim 100 \mathrm{~kb} 3^{\prime}$ to the $\beta$-globin gene (Elder et al. 1990). Using this probe, the parent SacI fragment is $10 \mathrm{~kb}$, and the sub-band in N-MEL chromatin is $1.5 \mathrm{~kb}$. Only a subset of the N-MEL samples in $A$ were used in $B$. The absence of this sub-band in T-MEL chromatin is indicated by an arrow in parentheses, as above. Maps of $3^{\prime} \beta$ and HPFH regions are derived from Henthorn et al. (1990) and Mager et al. (1985), respectively.

This is consistent with previous studies of the mouse $\beta^{\text {maj }}$ chromatin structure (Sheffery et al. 1982). Regardless of which restriction enzyme was used, both the $7-\mathrm{kb}$ EcoRI and 4.3-kb PstI fragments displayed similar preferential sensitivity to digestion by DNase I when compared to the restriction fragments shown in Figures 3 and 4 (Fig. 5 , cf. mouse $\beta^{\text {mai }}$ autoradiographs with the $5^{\prime} \epsilon$ and $3^{\prime} \beta$ autoradiographs). The EcoRI digested T-MEL filter was rehybridized with additional probes from the human $\beta$-globin gene $(5.5 \mathrm{~kb})$, the HPFH region $(5.0 \mathrm{~kb})$, and a region of DNA $\sim 15 \mathrm{~kb}$ upstream of the deletional breakpoint (the distant 5 ' $\epsilon$-globin region), 5' $\epsilon 2.5 \mathrm{Sph} / 4.1$ $\mathrm{kb}$. Although previous work has shown that the $\beta$ globin and HPFH regions reside within DNase I-sensitive chromatin (Forrester et al. 1986, Elder et al. 1990) and the distant $5^{\prime} \epsilon$-globin region is DNase I resistant in normal erythroid cells (Kioussis et al. 1983), all of these regions display the same DNase I-resistant pattern of digestion in T-MEL cells. These results indicate that the region deleted in the Hispanic thalassemia may be involved in the establishment of an erythroid-specific, DNase I-sensitive chromatin structure extending from the upstream $\epsilon$ region through the HPFH region.

\section{Replication}

Thus far, despite the presence of all structural $\beta$-like globin genes, all features associated with normal developmental activation of human $\beta$-like globin genes are absent in the Hispanic chromosome: $\beta$-globin RNA, protein, gene-specific and developmentally stable hypersen-

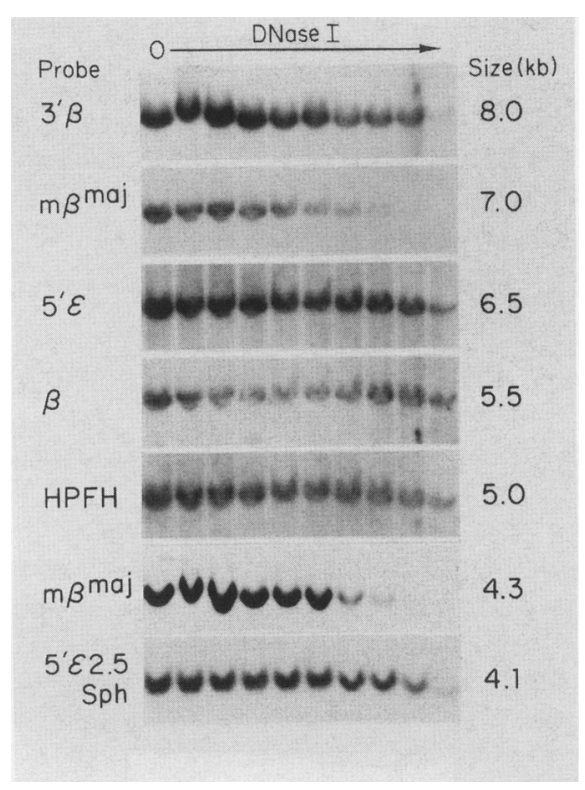

Figure 5. General DNase I sensitivity of the $\beta$-globin locus and flanking regions in T-MEL hybrids. (Human $\beta$-globin locus is DNase I resistant in T-MEL.) DNA samples described above from DNase I treated T-MEL nuclei were restricted with EcoRI in all cases except the $3^{\prime} \beta 8.0-\mathrm{kb}$ and mouse $\beta^{\text {maj }}\left(\mathrm{m} \beta^{\text {maj }}\right) 4.3-\mathrm{kb}$ autoradiographs, which were digested with PstI. All regions are from the human $\beta$-globin gene region of chromosome 11 except the $\mathrm{m} \beta^{\text {maj }}$ controls. Fragments are arranged in order of decreasing length. No hypersensitive sites were seen in the experiments from which these autoradipgraphs were excised (see Figs. 3 and 4). Locations of probes are described in the text. 
sitive sites, and the formation of a large, DNase I-sensitive chromatin domain. Replication in early $\mathrm{S}$ phase is another tissue-specific feature correlated with the expression of the $\beta$-globin locus in erythroid cells. Thus, we sought to determine whether the timing of replication is independent of transcriptional activity and/or chromatin structure in T-MEL cells, where all of the globin genes are DNase I resistant.

For this experiment, T-MEL cells were cultured in the presence of the thymidine analog bromodeoxyuridine (BrdU) for $1 \mathrm{hr}$, separated into size-dependent fractions by centrifugal elutriation, and analyzed by flow microfluorimetry (FMF) to determine the DNA content of cells within these fractions (Fig. 6A). Nuclear DNA was purified from selected fractions representing different points within $S$ phase, and restricted with EcoRI, and DNA that was replicating during the $1-\mathrm{hr}$ BrdU pulse was isolated from the individual fractions using $\mathrm{NaI}$ density gradients (see Materials and methods). This DNA has an increased density due to the incorporation of BrdU into the daughter strands and sediments faster as hybrid daughter/parental, heavy/light (H/L) DNA, whereas unreplicated DNA sediments as parental light/ light (L/L) DNA. The H/L DNA collected from each fraction was subsequently fractionated by agarose gel electrophoresis, blotted, and hybridized.

Because the probes used in this assay are well characterized and hybridize to unique EcoRI restriction fragments, several probes can be used simultaneously. We used probes from the distant $5^{\prime} \epsilon$-globin region $\left(5^{\prime} \in 2.5 \mathrm{Sph}\right)$, the $\epsilon$-globin gene, the human $\beta$-globin and flanking $3^{\prime} \beta$-globin region, and the distant $3^{\prime} \beta$-globin HPFH region. These probes provide a survey of $>185 \mathrm{~kb}$ of DNA in T-MEL cells. The results shown in Figure 6B compare the patterns of replication of this region from both the normal (N-MEL) and the deleted (T-MEL) chromosome 11 from this thalassemic individual to the endogenous mouse $\beta^{\text {mai }}$-globin gene.

Although the endogenous mouse $\beta^{\text {mai }}$-globin gene replicates similarly in both N-MEL and T-MEL cells, the human globin genes replicate at distinctly different times. In N-MEL cells, the human $\epsilon$ - and $\beta$-globin genes, the distant $5^{\prime} \in\left(5^{\prime} \in 2.5 \mathrm{Sph}\right)$, and the HPFH regions replicate in the same, early part of $\mathrm{S}$ phase as the endogenous mouse $\beta^{\text {mai }}$-globin gene control. In contrast, all human globin gene and distant $5^{\prime}$ and $3^{\prime}$ regions replicate late in $\mathrm{S}$ phase in T-MEL cells, including the $\gamma$ - and $\delta$-globin genes, as well as sequences located in between the $\beta$ -
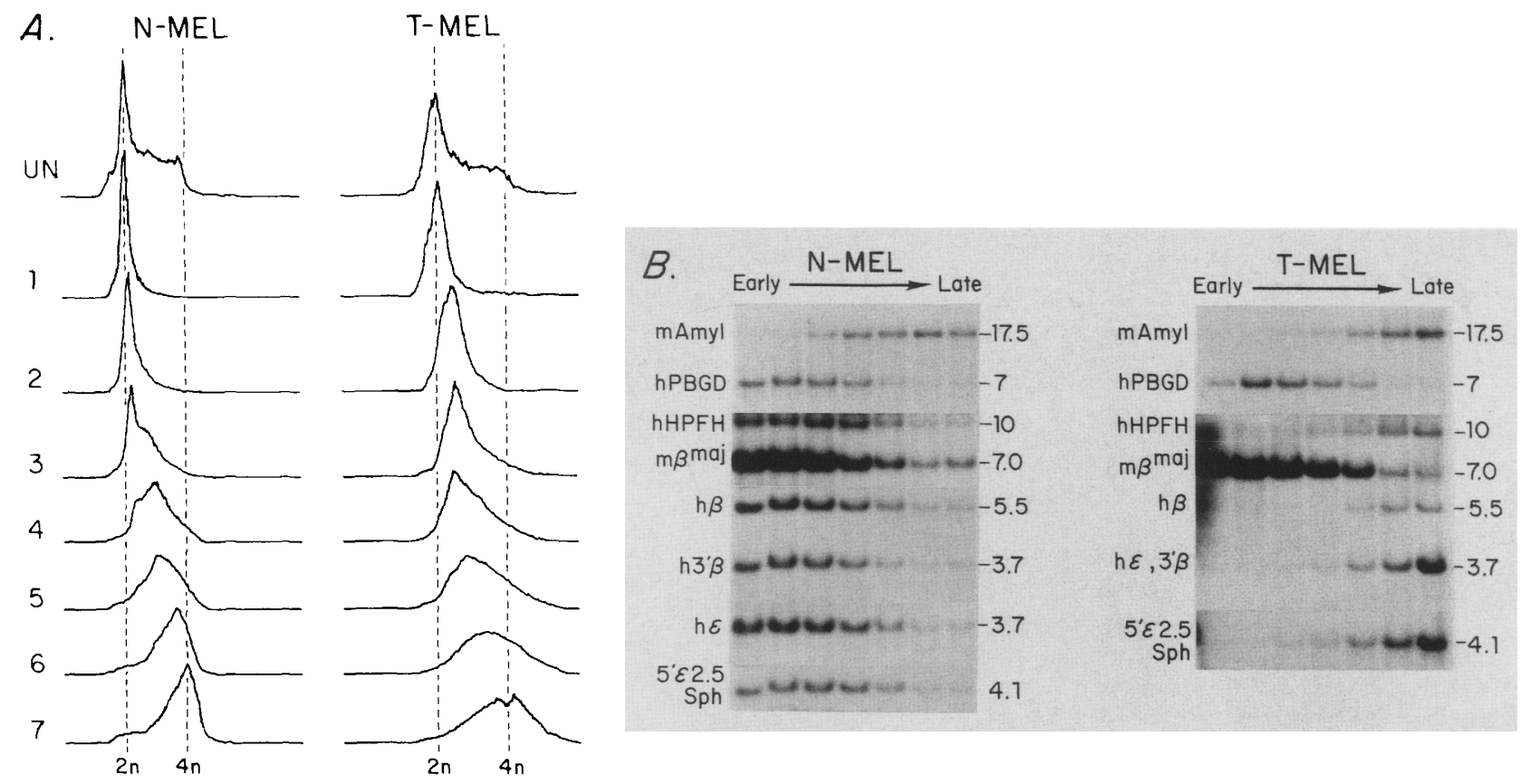

Figure 6. Replication of normal and deleted chromosome in MEL hybrids. (A) FMF analysis of elutriated, size-dependent fractions. Horizontal markers indicate increasing fluorescence per nucleus; vertical numbers indicate number of events per fluorescence channel; total events per sample $=5000$. Cells at the beginning of $S$ phase have $2 \mathrm{~N}$ DNA content, whereas cells having completed DNA synthesis have a $4 \mathrm{~N}$ DNA content. $(B)$ Five micrograms of replicated $(\mathrm{H} / \mathrm{L})$, EcoRI-cleaved DNA from individual cell-cycle fractions was run on $1 \%$ agarose gels, blotted, and hybridized to various probes. Each lane represents $H / L$ DNA from an elutriated fraction from early $S$ phase (left) to late $S$ phase (right). Lanes in both N-MEL and T-MEL correspond to traces numbered $1-7$ in $A$. The relatively strong hybridization signal to $\mathrm{m} \beta^{\text {maj }}$ probe is due to the presence of two or more copies per mouse haploid genome per cell, whereas human chromosome 11 is present at $\leqq 1$ copy per cell. The extended pattern of hybridization observed for the mouse $\beta^{\text {maj- }}$ globin gene is the result of size heterogeneity in the hybrid population. This makes the size-dependent fractions more heterogeneous in terms of synchrony in $\mathrm{S}$ phase. This can be seen in the relatively broad FMF profiles for individual fractions in $A$ (cf. with Epner et al. 1988). 
globin gene and HPFH region (data not shown). As an independent control for this experiment, both filters were rehybridized with probes from the human porphobilinogen deaminase (PBGD; Raich et al, 1986) and mouse amylase gene regions (Wiebauer et al. 1985). The human PBGD gene, which resides on chromosome 11 (Wang et al. 1981), replicates in the early part of S phase (see Fig. 6B). The mouse amylase gene replicates in the late part of S phase in both N-MEL and T-MEL cells, in agreement with previous results (Dhar et al. 1989). Thus, we conclude that the $35-\mathrm{kb}$ deletion associated with this novel thalassemia results in the failure to activate the chromatin structure of the $\beta$-globin locus /see above) and, in addition, prevents DNA synthesis in early $S$ phase over a larger region that includes sequences upstream of the deletion and as far away as the HPFH region, $>185 \mathrm{~kb} \mathrm{3}$.

\section{Discussion}

\section{Summary of results}

Our results (summarized in Fig. 7) show that the deletion leading to the Hispanic $(\gamma \delta \beta)^{0}$ thalassemia prevents the tissue-specific changes in chromatin structure and timing of replication that are presumably required for normal expression of any of the $\beta$-like globin genes. The globin locus on the Hispanic chromosome is DNase I-resistant, replicates late, and is devoid of both gene-specific and developmentally stable DNase I hypersensitive sites. At the level of chromatin structure, the effect of this deletion extends $3^{\prime}$ through regions close to the deletion breakpoint, to the $\beta$-globin gene $55 \mathrm{~kb}$ away and to a region $>100 \mathrm{~kb} 3^{\prime}$ of the $\beta$-globin gene (the HPFH locus) and may affect sequences even farther downstream. In addition, developmentally stable hypersensitive sites, which are found in erythroid cell precursors (Tuan et al. 1985; Forrester et al. 1986, 1987) and precede globin gene transcription, do not form on the Hispanic chromosome. Therefore, in the absence of the LAR, a region $>185 \mathrm{~kb}$ that normally resides within an erythroid-specific DNase I-sensitive configuration is DNase I resistant (Fig. 7).

We have also shown that the Hispanic deletion affects the replication timing of sequences in a bidirectional fashion. Previous work demonstrated that sequences $\sim 15 \mathrm{~kb}$ upstream of the $5^{\prime}$ deletion endpoint, within the 4.1-kb EcoRI fragment in Figure 4, are DNase I resistant in normal erythroid cells (Kioussis et al. 1983). Therefore, no alteration in the DNase I sensitivity of this region would be expected as a result of the Hispanic deletion. However, the replication timing of sequences within this region is clearly altered in the Hispanic deletion: On the deleted chromosome, these sequences replicate late in S phase, whereas the same sequences replicate early in $S$ phase on the normal chromosome (see Fig. 6B; Epner et al. 1988). Using cosmid probes, we have found that in N-MEL cells, early replicating DNA extends 5 ' for at least another $15 \mathrm{~kb} / \mathrm{W} . \mathrm{C}$. Forrester and $\mathrm{E}$. Epner, unpubl.). These results demonstrate that although chromatin structure is altered unidirectionally $3^{\prime}$ to the LAR by the deletion, replication timing is affected bidirectionally over $\sim 200 \mathrm{~kb}$ (Fig. 7). This suggests that the chromatin and replication effects of the LAR may be separable. The unidirectional changes in chromatin structure in the normal chromosome indicate that either the LAR inhibits the spread of DNase I-resistant chromatin farther downstream or sequences $5^{\prime}$ to the LAR prevent the spread of DNase I-sensitive chromatin farther upstream. The bidirectional effects on replication suggest that an origin of replication may be located within or near the LAR.

\section{Structure/function relationships}

The hypersensitive sites within the LAR were shown previously to be erythroid-specific, developmentally stable (Tuan et al. 1985; Forrester et al. 1986, 1987), and present prior to transcriptional activation of the globin
Figure 7. Summary. Erythroid-specific patterns of DNase I sensitivity, timing of DNA replication, and location of developmentally stable hypersensitive sites are shown for the $\beta$-like globin locus and flanking regions in normal and Hispanic chromosomes. Relative positions of the $\beta$-like globin genes, developmentally stable hypersensitive sites, the $\mathrm{HPFH}$ region, and the $5^{\prime}$ boundary of DNase I-sensitive chromatin are shown. Undetected hypersensitive sites in the Hispanic thalassemia are indicated by arrows with $\times$ above them, DNase I-resistant chromatin is represented by coiled lines, and DNase I-sensitive chromatin is represented by straight lines. The dashed coil in the normal chromosome shows the boundary region between DNase I-sensitive and DNase I-resistant chromatin in the $5^{\prime}$ flanking region. The open arrow above the normal chromosome line represents a nontissue-specific hypersensitive site described in the text.

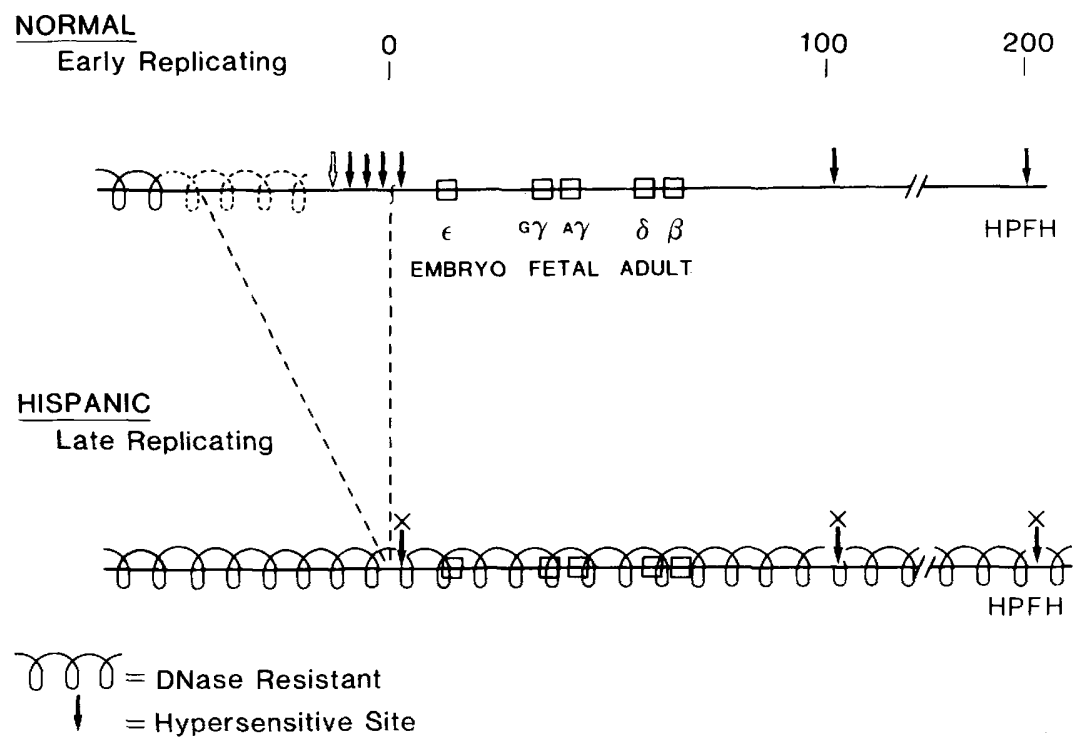


genes (Forrester et al. 1987). Stable assays in which the $\beta$-globin gene is linked to fragments of the LAR have revealed that in erythroid cells, sites II $(-10.9)$, III $(-14.7)$, and IV $(-18)$ confer elevated expression in the integrated state (Forrester et al. 1989; Collis et al. 1990). As measured in transient assays in MEL cells, site II possesses strong enhancer activity, whereas sites III and IV do not (Tuan et al. 1989).

The behavior of sites III and IV in functional assays resembles the A elements of the chicken lysozyme gene, which do not act like enhancers in transient assays but confer elevated expression in stable assays (Steif et al 1989). These elements that are thought to mediate attachment to the nuclear scaffold may define a novel type of regulatory element, which exerts its effect, in part, by alleviating inhibitory effects associated with random insertion into the host genome (position effects). Perhaps significantly, sequences lost in the Hispanic deletion contain nuclear scaffold attachment sites (Jarman and Higgs 1989|.

By analogy to the lysozyme control elements, it is possible that some sequences within the LAR confer position-effect independence, whereas other sequences may be more directly involved in transcriptional regulation. These distinctions are complex and require further experimentation. However, it is significant that in the absence of globin gene expression, the $\beta$-globin locus resides in a large DNase I-sensitive domain, hypersensitive sites are formed, and the locus is early replicating (Forrester et al. 1987; Epner et al. 1981, 1988), thereby dissociating these phenomena from transcriptional enhancer effects, per se.

Several of the hypersensitive sites within the LAR contain binding sites for proteins thought to be important for control of globin gene transcription. The A/ TGATAG/A motif is found at multiple positions at or near the -10.9 and -14.7 hypersensitive sites (sites II and III) within the LAR as well as elsewhere in the globin locus. This sequence binds a protein called GF-1 (Tsai et al. 1989), Eryfl (Evans et al. 1988), or NF-E1 (Wall et al. 1988), which was initially thought to be erythroid specific but was found subsequently in mast cells and megakaryocytes (Martin et al. 1990; Romeo et al. 1990). The $-6.1,-10.9,-14.7$, and -18 hypersensitive sites within the LAR are not present in megakaryocytes, however, indicating that in its native state in vivo, this factor alone cannot create any of these $5^{\prime} \epsilon$ hypersensitive sites (W.C. Forrester and L. Zon, unpubl.).

\section{Replication}

A number of studies have found that active or potentially active genes replicate in the first half of $S$ phase, whereas inactive genes replicate in the late half of $S$ phase (Goldman et al. 1984; Holmquist 1987). In multigene families, however, such as the $\alpha$ - and $\beta$-globin loci, all genes are replicated at the same time, regardless of transcriptional activity (Epner et al. 1988; Hatton et al. 1988). In erythroid cells, transcriptionally active and inactive genes within the $\alpha$ - and $\beta$-globin loci replicate early. In nonerythroid cells such as the lymphoblastoid cell line Manca, both the $\alpha$ - and $\beta$-globin loci are transcriptionally inactive and DNase I resistant (Yagi et al. 1986); however, the $\alpha$-globin locus replicates early, and the $\beta$-globin locus replicates late. These observations suggest that early replication may be necessary but not sufficient for the activation of transcription and/or the assembly of an active chromatin structure.

Our results show that the LAR affects replication timing in a bidirectional fashion over a large physical distance, from $70 \mathrm{~kb} 5^{\prime}$ to $\epsilon$ (from cosmid hybridizations) to $100 \mathrm{~kb} 3^{\prime}$ to $\beta$ (within the HPFH region), $\sim 220 \mathrm{~kb}$ total. This region includes sequences $5^{\prime}$ to the LAR, which are DNase I resistant in erythroid cells. Cytogenetic analyses of replication banding patterns within intact chromosomes have revealed that transcribed and nontranscribed regions appear to be contained within large domains that replicate at approximately the same time in S phase (for review, see Hand 1978; Holmquist 1987). Based on estimates of interorigin spacing, these chromosomal domains most likely consist of clusters of replicons. It is also possible that the large region in and around $\beta$-globin locus included in our replication analysis contains more than one replicon. Therefore, sequences in or near the LAR may control the timing of replication of these replicons in a concerted manner.

\section{Overview}

It is possible that sequences within the LAR facilitate the conversion to an early replicating domain, permitting other changes in chromatin structure that are recognized as DNase I sensitivity and hypersensitivity. This early replication, or locus activation, function may be due to elements such as origins of replication or matrix attachment sites within the LAR. Reorganization of the $\beta$-globin locus in this way might allow utilization of other elements, both within the LAR and the globin genes themselves, required for globin gene expression (discussed in Weintraub 1985).

A $38-\mathrm{kb} \beta$-globin minilocus containing the LAR appears to alleviate position effects resulting in per copy levels of $\beta$-globin transgene expression equivalent to the endogenous mouse globin genes (Grosveld et al. 1987). Furthermore, the LAR-linked transgenes are expressed in $>90 \%$ of the mice containing these transgenes (Ryan et al. 1989b). Other groups have also reported dramatic effects of the LAR on the frequency and level of transgene expression (Curtin et al. 1989; Talbot et al. 1989; Enver et al. 1990); however, due to variable levels of expression with similar minilocus constructs, the issue of the LAR influence on copy number-dependent, positionindependent expression remains to be resolved (Ryan et al. 1989b). Globin transgenes linked to the site II region alone are also highly expressed in most transgenic mice (Curtin et al. 1989; Ryan et al. 1989b), demonstrating that the effects on transgene expression do not require an intact LAR. Whether these results reflect the role of the LAR on the normal developmental activation of the $\beta$-globin domain or an enhancement of the intrinsic 
ability of individual $\beta$-globin transgenes to be appropriately expressed may prove difficult to determine in transgenic mice. Because the LAR is a large, complex regulatory region that may contain multiple regulatory elements, identifying sequence and structural homologies to the LAR in other species may help localize the features essential to LAR activity.

Our analysis of the Hispanic $(\gamma \delta \beta)^{0}$-thalassemia chromosome revealed considerable alterations in the chromatin structure and timing of replication when compared to the normal chromosome. Therefore, although the mechanism by which specific chromosomal domains are targeted for restructuring at the level of replication timing and/or chromatin is unknown, the (removal of the LAR in the) Hispanic deletion appears to define a region that may contain a master switch for these functions.

The availability of hybrid cell lines containing one copy of either the normal or deleted chromosome 11 provides a model system in which to define the contributions of individual components of the LAR to chromatin structure, replication timing, and/or transcriptional activation of the $\beta$-globin locus. For example, individual components of the LAR can be inserted or deleted via homologous recombination in their natural positions on mutant and normal chromosomes, and the effects of such alterations on the $\beta$-globin loci can be determined.

\section{Materials and methods}

\section{Somatic cell hybrids}

Lymphoid cells from a Hispanic thalassemia individual, immortalized with Epstein-Barr virus, were fused with MEL cells, selected, and propagated as described (Takegawa et al. 1986; Papayannopoulou et al. 1988). Briefly, MEL cells were mixed with human lymphoid cells at $1: 10$ ratio, and $50 \%$ polyethylene glycol (PEG, vol/vol) was added in RPMI-1640 media at $37^{\circ} \mathrm{C}$. Cells were then washed, resuspended in RPMI plus $10 \%$ fetal calf serum, and cultured for $48 \mathrm{hr}$ prior to selection for hybrid phenotype. MEL cells used for these fusions are ouabain resistant $\left(\mathrm{oua}^{\mathrm{r}}\right)$, and deficient for guanine-adenine phosphoribosyl transferase $\left(\right.$ aprt $\left.^{-}\right)$. Human lymphoid cells are ouabain sensitive (ouas) and aprt ${ }^{+}$. The hybrid phenotype is therefore ouar, aprt $^{+}$and is selected in ouabain, adenine, and alanosine. Further selection of these hybrids for the presence and maintenance of human chromosome 11 was accomplished by antibody-mediated culture dish binding (panning), using a monoclonal antibody (53/6) with affinity for a constitutively expressed surface antigen encoded by chromosome 11 (Yagi et al. 1987). The presence of this surface antigen does not constitute a selective pressure for $\beta$-globin gene expression.

\section{Isolation of nuclei, DNase I digestions, and purification of genomic DNA}

For chromatin experiments, cells growing in DME or RPMI plus $10 \%$ defined, supplemented calf serum were spun $1.2 \mathrm{~K}, 5$ min, $4^{\circ} \mathrm{C}$ in a Beckman J6-B centrifuge. Cell pellets were vortexed briefly, resuspended in cold reticulocyte standard buffer (RSB), and respun. Cell pellets were again resuspended in cold RSB, one-fifth volume of $0.5 \%$ NP-40 in RSB (final $\mathrm{NP}-40=0.1 \%$ ) was added, and cells were dounced 20 times with a B pestle. Dounced cells were transferred to a $50-\mathrm{ml}$ conical tube and diluted up to $50 \mathrm{ml}$ with cold RSB and spun $1.2 \mathrm{~K}$ for $5 \mathrm{~min}$ at $4^{\circ} \mathrm{C}$. Nuclei were resuspended in cold RSB to a final concentration of $1 \mathrm{mg} / \mathrm{ml}$, total nucleic acid content.

Preparation of nuclei for isolating genomic DNA to be used in restriction enzyme or replication studies was the same as above, except cells were resuspended in cold RSB, and one-half volume $0.5 \% \mathrm{NP}-40$ in RSB was added. The mixture was vortexed, and nuclei were pelleted by centrifugation at $1.2 \mathrm{~K}$, for 5 $\min$ at $4^{\circ} \mathrm{C}$.

Nuclei at $1 \mathrm{mg} / \mathrm{ml}$ in cold RSB $\left(\mathrm{OD}_{260}\right.$ on nuclei lysed in $2 \times$ stop) were distributed into several $15-\mathrm{ml}$ polyproylene tubes (2059 Falcon) on ice. Dilutions of stock DNase I solution (1 $\mathrm{mg} / \mathrm{ml}$ in $\mathrm{H}_{2} \mathrm{O}$, frozen, made from powder from Sigma, DN-EP, $D-1126)$ were added over a range (final) of $0.01-15.0 \mu \mathrm{g} / \mathrm{ml}$. After addition of DNase I to nuclei, tubes were vortexed quickly and placed in a $37^{\circ} \mathrm{C}$ water bath. Aliquots $(25-50 \mu \mathrm{l})$ were removed during the course of digestion with 9-inch Pasteur pipettes and pipetted up and down in $100 \mu \mathrm{l}$ of $2 \times[0.6 \mathrm{M}$ $\mathrm{NaCl}, 20 \mathrm{mM}$ Tris-Cl (pH 7.6), $10 \mathrm{~mm}$ EDTA, 1\% SDS] stop to monitor progressive decrease in viscosity. When the last tube in the series (i.e., highest amount of DNase I) was no longer visibly viscous, all reactions were stopped with equal volume of $2 \times$ stop containing $500 \mu \mathrm{g} / \mathrm{ml}$ proteinase $\mathrm{K}$. Time of DNase I digestions ranged from 10 to $30 \mathrm{~min}$.

Lysed nuclei were incubated at $37^{\circ} \mathrm{C}>3 \mathrm{hr}$, generally overnight, after which one-half volume of $7.5 \mathrm{M} \mathrm{NH}_{4} \mathrm{OAc}$ was added. Samples were vortexed thoroughly and precipitated by gently mixing with an equal volume of isopropanol. The precipitate was pelleted at $7 \mathrm{~K}$ (Sorvall SM-24 rotor) for $10 \mathrm{~min}$, resuspended in TE [10 mM Tris-Cl $(\mathrm{pH} 7.6), 1 \mathrm{~mm}$ EDTA], treated with $20-50 \mu \mathrm{g} / \mathrm{ml}$ heat-treated RNase A for $1-2 \mathrm{hr}$ at $37^{\circ} \mathrm{C}$, and precipitated with $\mathrm{NH}_{4} \mathrm{OAc}$ as described above. The final pellet was rinsed with $70 \%$ ETOH $5^{\prime}$ at room temperature and resuspended in TE.

\section{Southern blots}

Restriction enzyme digests were carried out according to the manufacturer's recommendations. For chromatin studies, $15-30 \mu \mathrm{g}$ of DNA per lane was used, and for replication studies, $5 \mu \mathrm{g}$ of $\mathrm{H} / \mathrm{L}$ DNA was loaded per lane. Agarose gels $(1 \%$ ) containing $1 \mu \mathrm{g} / \mathrm{ml}$ ethidium bromide were electrophoresed $\sim 16 \mathrm{hr}$ in $1 \times$ TAE $[0.04 \mathrm{M}$ Tris-Cl $(\mathrm{pH} 7.5), 0.02 \mathrm{M}$ $\mathrm{NaOAc}, 0.002 \mathrm{M}$ EDTA], with one or two changes of TAE buffer during the run. Gels were photographed, depurinated for $10 \mathrm{~min}$ at room temperature in $1.5 \mathrm{M} \mathrm{NaCl}, 20 \mathrm{mM} \mathrm{HCl}$, and denatured in $1.5 \mathrm{M} \mathrm{NaCl}, 0.5 \mathrm{M} \mathrm{NaOH} 2 \times 10 \mathrm{~min}$, followed by a $10-\mathrm{min}$ soak in $1.5 \mathrm{M} \mathrm{NaCl}, 0.25 \mathrm{M} \mathrm{NaOH}$. DNA was transferred to GeneScreen Plus membranes premoistened in water, by base transfer method (i.e., transfer solution is $1.5 \mathrm{M} \mathrm{NaCl}, 0.25 \mathrm{M}$ $\mathrm{NaOH}$ ). After transfer (7-hr minimum), filters were rinsed twice in $2 \times$ SSC, air-dried, prehybridized, and hybridized. Prehybridization was done at $42^{\circ} \mathrm{C}$, for $15 \mathrm{~min}$ minimum in $5 \times$ SSC, $25 \mathrm{~mm} \mathrm{NaP}$ (pH 6.5), 0.02\% Denhardt's (50× Denhardt's is $1 \%$ Ficoll, $1 \%$ polyvinylpyrrolidone, $1 \%$ BSAl, $250 \mu \mathrm{g} / \mathrm{ml}$ sonicated salmon sperm DNA, $50 \%$ formamide, $1 \%$ powdered milk, and $3 \%$ SDS. Hybridizations were also done at $42^{\circ} \mathrm{C}$, in prehybridization solution with $8 \%$ dextran sulfate. Nicktranslated probe $\left(1 \times 10^{6}\right.$ to $\left.2 \times 10^{6} \mathrm{cpm}\right)$ was heat-denatured, chilled on ice, and added to hybridization solution at $65^{\circ} \mathrm{C}$. Hybridization solution including probe was added to membrane and placed at $65^{\circ} \mathrm{C}$ for $15 \mathrm{~min}$, after which it was transferred to $42^{\circ} \mathrm{C}$ for $18 \mathrm{hr}$. Filters were washed for $10 \mathrm{~min}$ at $50-60^{\circ} \mathrm{C}$ in $2 \times \mathrm{SSC}, 0.1 \%$ SDS, and then for $10-20 \mathrm{~min}$ at $65^{\circ} \mathrm{C}$ in $0.1 \times$ SSC, $0.1 \%$ SDS. 


\section{Replication}

Replication assays were performed essentially as described by Epner et al. (1988). Hybrids kept at log-phase growth in RPMI or DME plus $10 \%$ serum were incubated for $1 \mathrm{hr}$ with $20 \mu \mathrm{g} / \mathrm{ml}$ BrdU (Sigma B-5002), centrifuged in the presence of excess thymidine (100 $\mu \mathrm{g} / \mathrm{ml}$; Sigma T-5018), washed with cold PBS, and separated into size-dependent fractions by centrifugal elutriation. Aliquots were analyzed for position in the cell cycle by FMF. Nuclei were isolated, and purified nuclear DNA was digested with EcoRI. Newly replicated BrdU-containing DNA was separated from unreplicated DNA by $\mathrm{NaI}$ density gradient centrifugation $(\mathrm{RI}=1.4360)$ containing ethidium bromide $(20$ $\mu \mathrm{g} / \mathrm{ml}) . \mathrm{H} / \mathrm{L}$ DNA was collected by drip method, and 8 - to $12-\mathrm{ml}$ collected volumes were dialyzed against $0.01 \times \mathrm{TE}$, concentrated by butanol extraction, and precipitated by adding one-half volume $7.5 \mathrm{M} \mathrm{NH}_{4} \mathrm{OAc}$ and an equal volume of isopropanol. Five micrograms of BrdU-DNA from each of the cellcycle fractions was then electrophoresed through $1 \%$ agarose gels and blotted as described above.

Elutriation was carried out in a modified Beckman J-6B centrifuge with a $40-\mathrm{ml}$ Beckman JE-5.0 elutriation rotor. Approximately $0.5 \times 10^{9}$ to $2 \times 10^{9}$ cells were labeled with BrdU for 1 $\mathrm{hr}$ and collected by repeated centrifugations at $1.2 \mathrm{~K}$, for $5 \mathrm{~min}$ in $J-6 \mathrm{~B}$ centrifuge were used in a single experiment. The final cell pellet was resuspended to a final volume of $15 \mathrm{ml}$ of $1: 1$, TBS/Versene plus $5 \%$ Calf serum (TBS is 24 grams NaCl, 1.14 grams $\mathrm{KCl}, 0.3$ grams $\mathrm{Na}_{2} \mathrm{HPO}_{4}, 3.0$ grams dextrose, 9.0 grams Trizma base per 3 liters at $\mathrm{pH} 7.4$ with $\mathrm{HCl}$; Versene is 0.2 grams $\mathrm{KCl}, 1.15$ grams $\mathrm{Na}_{2} \mathrm{HPO}_{4}, 8$ grams $\mathrm{NaCl}, 0.2$ grams $\mathrm{KH}_{2} \mathrm{PO}_{4}, 0.2$ grams EDTA per liter at $\mathrm{pH} 7.2$ with $\mathrm{HCl}$ ) and loaded into an elutriator injection chamber. Load conditions for elutriation were $25 \mathrm{ml} / \mathrm{min}$ flow at $1800 \mathrm{rpm}$. Both flow and rpm were adjusted during the load to maintain cells within the elutriation chamber. At the end of the load, settings were $40-50 \mathrm{ml} / \mathrm{min}$ at $1750 \mathrm{rpm}$ but these conditions varied, depending on the volume and type of cells loaded into the chamber. Two-hundred milliliters of elutriated size-dependent fractions in TBS/Versene plus $5 \%$ serum were collected by increasing flow in increments of $10 \mathrm{ml} / \mathrm{min}$ while maintaining constant rpm. Cellular volumes were monitored on a Coulter counter during the elutriation to ascertain the progress and quality of the size separation. Routinely, 10-15 fractions were collected and stained with propidium iodide to determine DNA content per cell. Samples representing different stages of $S$ phase, that is, increasing amounts of DNA per nucleus (see Fig. 6A), were selected, and nuclear DNA was prepared as described above. Genomic DNA (0.5-1 mg), isolated from these samples, was digested with EcoRI and separated into $\mathrm{H} / \mathrm{L}$ and $\mathrm{L} / \mathrm{L}$ fractions by density gradient centrifugation (see above).

\section{RNase Protections}

Preparation of total cellular RNA and probes, and RNase protection are as described by Enver et al. (1990).

\section{Acknowledgments}

We thank George Stamatoyannopoulos for encouragement. We also thank Robert Benezra, Robert Davis, Shlomo Handeli and, especially, Keith Blackwell for comments on the manuscript, Hal Weintraub and members of the Groudine lab for helpful discussions, Jeanette Kosugi for excellent technical assistance, Deb Gumucio (University of Michigan) for generosity in supplying mouse amylase probes, Carl Schildkraut (Albert Einstein) for a mouse amylase probe, Frank Grosveld (MRC, Mill
Hill) for human $\beta$-globin locus cosmids, Russell Kaufman (Duke) for $3^{\prime} \beta$ probes, Natacha Raich (University of Washington) for the PBGD probe, Robert Benezra for the $3^{\prime}$ mouse $\beta^{\text {maj }}$ probe, Roger Korneluk (Children's Hospital, Ottawa) for catalase probes, Dixie Mager (Terry Fox, Vancouver) for several probes in the $3^{\prime} \beta$ and HPFH region, and J.T. Elder (University of Michigan/ for HPFH probes. This work was supported by U.S. Public Health Service grants DK-31232 to M.G. and DK-31212 and DK-30852 to T.P., a Cooley's Anemia Foundation award to T.E., an National Institute of Health training grant 2-T32CA09437-03 to W.C.F., and a grant from the James McDonnell Foundation to E.E.

The publication costs of this article were defrayed in part by payment of page charges. This article must therefore be hereby marked "advertisement" in accordance with 18 USC section 1734 solely to indicate this fact.

\section{References}

Baron, M. and T. Maniatis. 1986. Rapid reprogramming of globin gene expression in transient heterokaryons. Cell 46: 591-602.

Behringer, R.R., T.M. Ryan, R.D. Palmiter, R.L. Brinster, and T.M. Townes. 1990. Human $\gamma$ - to $\beta$-globin gene switching in transgenic mice. Genes Dev. 4: 380-389.

Behringer, R.R., T.M. Ryan, M.P. Reilly, T. Asakura, R.D. Palmiter, R.L. Brinster, and T.M. Townes. 1989. Synthesis of functional human hemoglobin in transgenic mice. Science 245: 971-973.

Blom van Assendelft, G., O. Hanscombe, F. Grosveld, and D.R. Greaves. 1989. The $\beta$-globin dominant control region activates homologous and heterologous promoters in a tissuespecific manner. Cell 56: 969-977.

Chada, K., J. Magram, and F. Constantini. 1986. An embryonic pattern of expression of a human fetal globin gene in transgenic mice. Nature 319: 685-687.

Charnay, P., R. Treisman, P. Mellon, M. Chao, R. Axel, and T. Maniatis. 1984. Differences in human $\alpha$ - and $\beta$-globin gene expression in mouse erythroleukemia cells: The role of in tragenic sequences. Cell 38: 251-264.

Choi, O.R. and J.D. Engel. 1988. Developmental regulation of $\beta$-globin gene switching. Cell 55: 17-26.

Cohen, R. and M. Sheffery. 1985. Nucleosome disruption precedes transcription and is largely limited to the transcribed domain of globin genes in murine erythroleukemia cells. $J$. Mol. Biol. 182: 109-129.

Collins, F.S., J.L. Cole, W.K. Lockwoood, M.C. Iannuzzi. 1987. The deletion in both common types of hereditary persistence of fetal hemoglobin is approximately $105 \mathrm{~kb}$. Blood 70: $1797-1803$.

Collis, P., M. Antoniou, and F. Grosveld. 1990. Definition of the minimal requirements within the human $\beta$-globin gene and the dominant control region for high level expression. EMBO J. 9: 233-240.

Curtin, P., D. Liu, W. Liu, J.C. Chang, and Y.W. Kan. 1989. Human $\beta$-globin gene expression in transgenic mice is enhanced by a distant DNase I hypersensitive site. Proc. Natl. Acad. Sci. 86: 7082-7086.

Curtin, P., M. Pirastu, Y.W. Kan, J.A. Gobert-Jones, A.D. Stephens, H. Lehmann. 1985. A distant deletion affects $\beta$ globin gene function in an atypical $\gamma \delta \beta$-thalassemia. J. Clin. Invest. 76: 1554-1558.

Dhar, V., A.I. Skoultchi, and C.L. Schildkraut. 1989. Activation and repression of a $\beta$-globin gene in cell hybrids is accom panied by a shift in its temporal replication. Mol. Cell. Biol. 9: $3524-3532$. 
Dhar, V., D. Mager, A. Iqbal, and C.L. Schildkraut. 1988. The coordinate replication of the human $\beta$-globin gene domain reflects its transcriptional activity and nuclease hypersensitivity. Mol. Cell. Biol. 8: 4958-4965.

Deisseroth, A. and D. Hendrick. 1978. Human $\alpha$-globin expression following chromosomal dependent gene transfer into mouse erythroleukemia cells. Cell 15: 55-63.

Driscoll, C., C.S. Dobkin, and B.P. Alter. 1989. $\gamma \delta \beta$ thalassemia due to a de novo mutation deleting the $5^{\prime} \beta$-globin locus activating region hypersensitive sites. Proc. Natl. Acad. Sci. 86: $7470-7474$.

Elder, J.T., W.C. Forrester, C. Thompson, D. Mager, P. Henthorn, M. Peretz, T. Papayannopoulou, G. Stamatoyannopoulos and M. Groudine. 1990. Translocation of an erythroid-specific hypersensitive in deletion-type hereditary persistence of fetal hemoglobin. Mol. Cell. Biol. 10: 13821389.

Enver, T., N. Raich, A.J. Ebens, T. Papayannopoulou, and G. Stamatoyannopoulos. 1990. Developmental regulation of human fetal-to-adult globin gene switching in transgenic mice. Nature 344: 309-313.

Epner, E., W.C. Forrester, and M. Groudine. 1988. Asynchronous DNA replication within the human $\beta$-globin gene locus. Proc. Natl. Acad. Sci. 85: 8081-8085.

Epner, E., R. Rifkind, and P.A. Marks. 1981. Replication of $\alpha$ and $\beta$ globin DNA sequences occurs during early $S$ phase in murine erythroleukemia cells. Proc. Natl. Acad. Sci. 78: 3058-3062.

Evans, T., M. Reitman, and G. Felsenfeld. 1988. An erythrocyte-specific DNA binding factor recognizes a regulatory sequence common to all chicken globin genes. Proc. Natl. Acad. Sci. 85: 5976-5980.

Forrester, W.C., U. Novak, R. Gelinas, and M. Groudine. 1989. Molecular analysis of the human $\beta$-globin locus activation region. Proc. Natl. Acad. Sci. 86: 5439-5443.

Forrester, W.C., C. Thompson, J.T. Elder, and M. Groudine. 1986. A developmentally stable chromatin structure in the human $\beta$-globin gene cluster. Proc. Natl. Acad. Sci. 83: $1359-1363$.

Forrester, W.C., S. Takegawa, T. Papayannopoulou, G. Stamatoyannopoulos, and M. Groudine. 1987. Evidence for a locus activation region: The formation of developmentally stable hypersensitive sites in globin expressing hybrids. Nucleic Acids Res. 15: 10159-10177.

Gallarda, J.L., K.P. Foley, Z. Yang, and J.D. Engel. 1989. The $\beta$-globin stage selector element factor is erythroid-specific promoter/enhancer binding protein NF-E4. Genes Dev. 3: $1845-1859$.

Goldman, M.A., G.P. Holmquist, M.C. Gray, L.A. Caston, and A. Nag. 1984. Replication timing of genes and middle repetitive sequences. Science 224: 686-692.

Grosveld, F., G. Blom van Assendelft, D.R. Greaves, and G. Kollias. 1987. Position-independent, high level expression of the human $\beta$-globin gene in transgenic mice. Cell 51: 975985.

Groudine, M., R. Eisenman, R. Gelinas, and H. Weintraub. 1983a. Developmental aspects of chromatin structure and gene expression. In Globin gene expression and hematopoietic differentiation, (ed. G. Stamatoyannopoulos and A.W. Nienhuis), pp. 159-182. Alan R. Liss, New York.

Groudine, M., T. Kohwi-Shigematsu, R. Gelinas, G. Stamatoyannopoulos, and T. Papayannopoulou. 1983b. Human fetal-to-adult hemoglobin switching: Changes in chromatin structure of the $\beta$-globin gene locus. Proc. Natl. Acad. Sci. 80: $7551-7555$.

Hand, R. 1978. Eucaryotic DNA: Organization of the genome for replication. Cell 15: 317-325.

Hatton, K.S., V. Dhar, E.H. Brown, M.A. Iqbal, S. Stuart, V.T. Didamo, and C.L. Schildkraut. 1988. Replication program of active and inactive multigene families in mammalian cells. Mol. Cell. Biol. 8: 2149-2158.

Henthorn, P.S., O. Smithies, and D.L. Mager. 1990. Molecular analysis of deletions in the human $\beta$-globin gene cluster: Deletion junctions and locations of breakpoints. Genomics 6: 226-237.

Holmquist, G.P. 1987. Role of replication time in the control of tissue-specific gene expression. Am. I. Hum. Genet. 40: $151-173$.

Jarman, A.P. and D.R. Higgs. 1989. Nuclear scaffold attachment sites in the human globin gene complexes. $E M B O J$. 7: 3337-3344.

Karlsson S. and A.W. Nienhuis. 1985. Developmental regulation of human globin genes. Annu. Rev. Biochem. 54: $1071-1108$.

Kioussis, D., E. Vanin, T. deLange, R.A. Flavell, and F.G. Grosveld. 1983. $\beta$-Globin gene inactivation by DNA translocation in $\gamma \beta$-thalassemia. Nature 306: 662-666.

Kollias, G., N. Wrighton, J. Hurst, and F. Grosveld. 1986. Regulated expression of human $A \gamma-, \beta$ - and hybrid $\gamma / \beta$-globin genes in transgenic mice: Manipulation of the develop mental expression patterns. Cell 46: 89-94.

Mager, D.L., P.S. Henthorn, and O. Smithies. 1985. A Chinese ${ }^{G} \gamma^{+}(A \gamma \delta \beta)^{O}$ thalassemia deletion: Comparison to other deletions in the human $\beta$-globin gene cluster and sequence analysis of the breakpoints. Nucleic Acids Res. 13: 6559-6575.

Magram, J., K. Chada, and F. Constantini. 1985. Developmental regulation of a cloned adult $\beta$-globin gene in transgenic mice. Nature 315: 338-340.

Martin, D.I.K., L.I. Zon, G. Mutter, and S.H. Orkin. 1990. Expression of an erythroid transcription factor in megakaryocytic and mast cell lineages. Nature 344: 444-447.

Novak, U., E.A.S. Harris, W. Forrester, M. Groudine, and R. Gelinas. 1990. High-level $\beta$-globin expression after retroviral transfer of locus activation region-containing human $\beta$-globin gene derivatives into murine erythroleukemia cells. Proc. Natl. Acad. Sci. 87: 3386-3390.

Papayannopoulou, T., M. Brice, and G. Stamatoyannopoulos. 1986. Analysis of human hemoglobin switching in MEL $\times$ human fetal erythroid cell hybrids. Cell 46: 469-476.

Papayannopoulou, T., T. Enver, S. Takegawa, N.P. Anagnou, and G. Stamatoyannopoulos. 1988. Activation of developmentally mutated human globin genes by cell fusion. Science 242: 1056-1058.

Pyati, J., R.S. Kucherlapati, and A.I. Skoultchi. 1980. Activation of human $\beta$-globin genes from non-erythroid cells by fusion with murine erythroleukemia cells. Proc. Nat1. Acad. Sci. 77: 3435-3439.

Quan, F., R.G. Korneluk, M.B. Tropak, and R.A. Gravel. 1986. Isolation and characterization of the human catalase gene. Nucleic Acids Res. 14: 5321-5335.

Raich, N., P. Romeo, A. Dubart, D. Beaupain, M. Cohen-Solal, and M. Goossens. 1986. Molecular cloning and complete primary sequence of human erythrocyte porphobilinogen deaminase. 1986. Nucleic Acids Res. 14: 5955-5968.

Raich, N., V. Mignotte, A. Dubart, D. Beaupain, P. Leboulch, M. Romana, C. Chabret, P. Charnay, T. Papayannopoulou, M. Goossens, and P. Romeo. 1989. Regulated expression of the overlapping ubiquitous and erythroid transcription units of the human porphobilinogen deaminase (PBG-D) gene introduced into non-erythroid and erythroid cells. I. Biol. Chem. 264: 10186-10192.

Romeo, P.-H., M.-H. Prandini, V. Joulin, V. Mignotte, M. 
Prenant, W. Vainchenker, G. Marguerie, and G. Uzan. 1990. Megakaryocytic and erythroid lineages share specific transcription factors. Nature 344: 447-449.

Ryan, T.M., R.R. Behringer, T.M. Townes, R.D. Palmiter, and R.L. Brinster. 1989a. High level erythroid expression of human $\alpha$-globin genes in transgenic mice. Proc. Natl. Acad. Sci. 86: 37-41.

Ryan, T.M., R.R. Behringer, N.C. Martin, T.M. Townes, R.D. Palmiter, and R.L. Brinster. 1989b. A single erythroid-specific DNase I super-hypersensitive site activates high levels of human $\beta$-globin gene expression in transgenic mice. Genes Dev. 3: 314-323.

Sheffery, M., R.A. Rifkind, and P.A. Marks. 1982. Murine erythroleukemia cell differentiation: DNase I hypersensitivity and DNA methylation near the globin genes. Proc. Natl. Acad. Sci. 79: 1180-1184.

Stamatoyannopoulos, G. and A.W. Nienhuis. 1987. Hemoglobin switching and disorders of hemoglobin synthesis: The thalassemias. In The molecular basis of blood diseases led. G. Stamatoyannopoulos, A.W. Nienhuis, P. Leder, and P.W. Majerus), pp. 66-126. W.B. Saunders Co., Philadelphia.

Steif, A., D.M. Winter, W.H. Stratling, and A. Sippel. 1989. Nuclear attachment element mediates elevated and position independent gene activity. Nature 341: 343-345.

Takegawa, S., M. Brice, G. Stamatoyannopoulos, and T. Papayannopoulou. 1986. Only adult hemoglobin is produced in fetal nonerythroid $\times$ MEL cell hybrids. Blood 68: 13841388.

Talbot, D., P. Collis, M. Antoniou, M. Vidal, F. Grosveld, and D.R. Greaves. 1989. A dominant control region from the human $\beta$-globin locus conferring integration site-independent gene expression. Nature 338: 352-355.

Taramelli, R., D. Kioussis, E. Vanin, K. Bartram, J. Groffen, J. Hurst, and F.G. Grosveld. 1986. $\gamma \beta$ thalassemias 1 and 2 are the result of a $100 \mathrm{~kb}$ deletion in the human $\beta$-globin gene cluster. Nucleic Acids Res. 14: 7017-7029.

Townes, T.M., J.B. Lingrel, H.Y. Chen, R.L. Brinster, and R.D. Palmiter. 1985. Erythroid-specific expression of human $\beta$ globin genes in transgenic mice. EMBO J. 4: 1715-1723.

Tsai, S.-F., D.I.K. Martin, L.I. Zon, A.D. D'Andrea, G.G. Wong, and S.H. Orkin. 1989. Cloning of cDNA for the major DNAbinding protein of the erythroid lineage through expression in mammalian cells. Nature 339: 446-451.

Tuan, D., W. Solomon, L. Qiliang, and I.M. London. 1985. The " $\beta$-like-globin" gene domain in human erythroid cells. Proc. Nat1. Acad. Sci. 82: 6384-6388.

Tuan, D.Y., W.B. Solomon, I.M. London, and D.P. Lee. 1989. An erythroid-specific, developmental-stage independent enhancer far upstream of the human " $\beta$-like globin" genes. Proc. Natl. Acad. Sci. 86: 2554-2558.

Tuan, D., E. Feingold, M. Newman, S.M. Weissman, and B.G. Forget. 1983. Different $3^{\prime}$ end-points of deletions causing $\delta \beta$-thalassemia and hereditary persistence of fetal hemoglobin: Implications for the control of $\gamma$-globin gene expression in man. Proc. Natl. Acad. Sci. 80: 6937-6941.

Van der Ploeg, L.H.T., A. Konings, M. Oort, D. Roos, L. Bernini, and R.A. Flavell. 1980. $\gamma-\beta$-thalassemia studies showing that deletion of the $\gamma$ - and $\delta$-genes influences $\beta$-globin gene expression in man. Nature 283: 637-642.

Van Heyningen, V., P.A. Boyd, A. Seawright, J.M. Fletcher, J.A. Fantes, K.E. Buckton, G. Spowart, D.J. Porteous, R.E. Hill, M.S. Newton, and N.D. Hastie. 1985. Molecular analysis of chromosome 11 deletions in aniridia-Wilm's tumor syndrome. Proc. Natl. Acad. Sci. 82: 8592-8596.

Wall, L., E. deBoer, and F. Grosveld. 1988. The human $\beta$-globin gene 3 ' enhancer contains multiple binding sites for an ery- throid-specific protein. Genes Dev. 2: 1089-1100.

Wang, A.L., F.X. Arredondo-Vega, P.F. Giampietro, M. Smith W.F. Anderson, and R.J. Desnick. 1981. Regional assignment of human porphobilinogen deaminase and esterase $A$ to chromosome 1lq23 leads to 1lqter. Proc. Natl. Acad. Sci. 78: $5734-5738$.

Weintraub, H. 1985. The assembly and propagation of repressed and derepressed chromosomal states. Cell 42: 705-711.

Wiebauer, K., D.L. Gumucio, J.M. Jones, R.M. Caldwell, H.T. Hartle, and M.H. Meisler. 1985. A 78-kilobase region of mouse chromosome 3 containing salivary and pancreatic amylase genes and a pseudogene. Proc. Natl. Acad. Sci. 82: $5446-5449$.

Willing, M.C., A.W. Nienhuis, and W.F. Anderson. 1979. Selective activation of human $\beta$-globin but not $\gamma$-globin gene in human fibroblast $\times$ mouse erythroleukemia cell hybrids. Nature 277: 534-538.

Wood, W.G., J.B. Clegg, and D.J. Weatherall. 1979. Hereditary persistence of fetal hemoglobin (HPFH) and $\delta \beta$-thalassemia. Br. J. Hematol. 43: 509-520.

Wright, S., E. deBoer, F.G. Grosveld, and R.A. Flavell. 1983. Regulated expression of the human $\beta$-globin gene family in murine erythroleukemia cells. Nature 305: 333-336.

Wright, S., A. Rosenthal, R. Flavell, and F. Grosveld. 1984. DNA sequences required for regulated expression of $\beta$ globin genes in murine erythroleukemia cells. Cell 38: 265273.

Yagi, M., G. Stamatoyannopoulos, and T. Papayannopoulou. 1987. Monoclonal antibody 53.6 recognizes a novel proliferation-associated antigen encoded on human chromosome 11. I. Immunol. 136: 2208-2212.

Yagi, M., R. Gelinas, J.T. Elder, M. Peretz, T. Papayannopoulou, G. Stamatoyannopoulos, and M. Groudine. 1986. Chromatin structure and developmental expression of the human $\alpha$-globin cluster. Mol. Cell. Biol. 6: 1108-1116. 


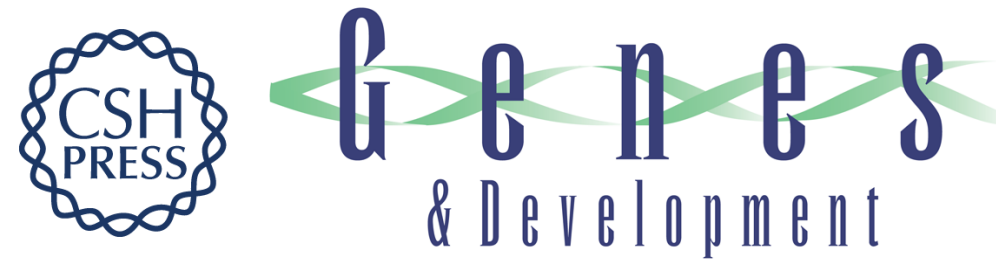

\section{A deletion of the human beta-globin locus activation region causes a major alteration in chromatin structure and replication across the entire beta-globin locus.}

W C Forrester, E Epner, M C Driscoll, et al.

Genes Dev. 1990, 4:

Access the most recent version at doi:10.1101/gad.4.10.1637

References This article cites 71 articles, 33 of which can be accessed free at:

http://genesdev.cshlp.org/content/4/10/1637.full.html\#ref-list-1

License

Email Alerting

Service

Receive free email alerts when new articles cite this article - sign up in the box at the top right corner of the article or click here.

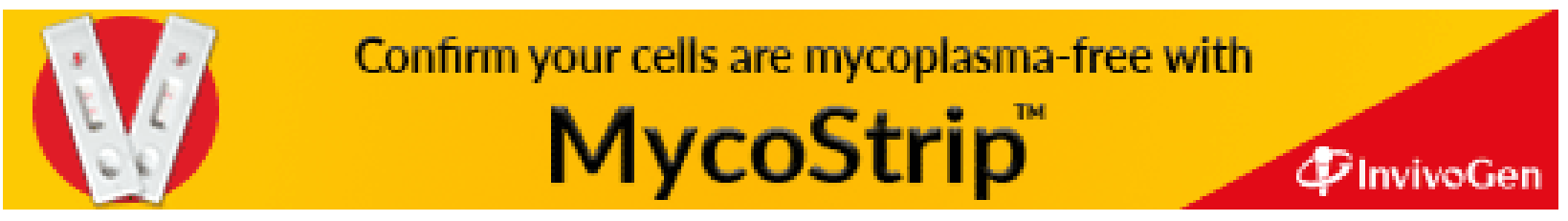

